\title{
肺転移を有する肝芽腫に対する治療戦略
}

\author{
広島大学第 1 外科, 同 総合診療部* \\ 山岡 裕 明檜 山英 三* 横 山 隆*

\section{Treatments for Hepatoblastoma with Lung Metastasis}

\author{
Hiroaki YAMAOKA, Eiso HIYAMA* and Takashi YOKOYAMA* \\ First Department of Surgery, *Department of General Medicine, \\ Hiroshima University Faculty of Medicine
}

従来, 外科治療のみでは治療が困難な肺転移を有する肝芽腫進行例, 再発例の治療成績は悪く, 肺転移は予後 不良因子の 1 つと考えられていたが, 最近集学的治療にて治癒する報告がなされてきている。当院では肺転移を 有する進行肝芽腫の 4 症例を経験した。症例は全例男児で, 組織型は 1 例がpoorly differentiated typeで, 3 例 はwell differentiated typeであった。初診時肺転移を 2 例に認め, 1 例は化学療法で肺転移は消失したが, 1 例 は化学療法後に外科的摘出術を行った。後者は肺転移巣が再発し, 再摘出後に 2 度目の骨䯣移植を行って生存中 である。また, 治療中肺転移を示した症例は 2 例で， 1 例は化学療法で肺転移は消失し，1例は外科的摘出術を 行い骨髄移植を併用し，良好な成績を得た。

肝芽腫の肺転移に対しては, 化学療法を第一とし，その後に可能な症例では残存する転移巣を積極的に切除し， 骨髄移植を併用した大量化学療法が有効と考えられた。

索引用語：肝芽腫 (hepatoblastoma), 肺転移 (lung metastasis), 外科治療 (surgery), 化学療法 (chemotherapy), 骨髄移植 (stem cell transplantation)

\section{はじめに}

かつては肝芽腫は化学療法に対する反応性が乏 しく, 外科治療が唯一の治療手段とされた時代も あったが, 近年化学療法の有効性が示されるよう になり，術前の化学療法によるdelayed primary 手術や, 術前transcatheter arterial embolization

(TAE) 療法の有効な症例も報告されて, それに 伴い外科治療のあり方が一変してきた。従来, 外 科治療のみでは治療が困難な肺転移を伴う進行 例, 再発例の治療成績は悪く, 肺転移は予後不良 因子の 1 つと考えられていたが，化学療法ととも に積極的な外科治療および自家骨髄移植の導入な ど集学的治療にて治癒する報告がなされてきてい
る1) 8)。当院では肺転移をともなう進行肝芽腫の 4 症例を経験し，2例は化学療法で治癒し， 2 例 は肺部分切除を行い，その内 3 例は自家骨䯣移植 を導入した化学療法を行い良好な成績を得ている ので，肝芽腫特に肺転移を伴う進行例に対する外 科治療のあり方について文献的考察を加え報告す る。

\section{症例}

症例 $1: 3$ 歳 5 力月, 男児 (Fig. 1)。

既往歴：特記すべき事なし。

現病歴：発熱および腹痛を主訴に近医受診し, 腹部腫瘤を認め, 総合病院を紹介される。CTにて 肝右葉に $11 \times 9 \mathrm{~cm}$ 大の腫瘍を認め, $\alpha$-feto- 


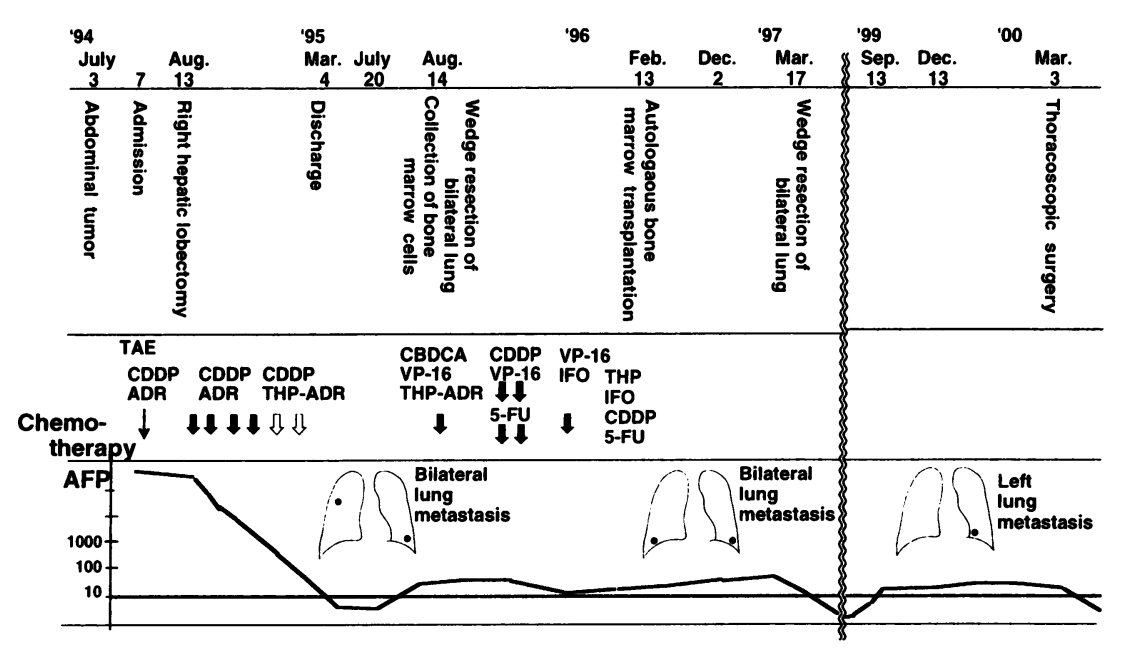

Fig. 1 Clinical course of case 1

protein (AFP) は $742,990 \mathrm{ng} / \mathrm{ml}$ と高値で，肝芽腫 を疑われ当科へ紹介入院となった。

入院後, TAEおよび肝動注化学療法 (CDDP 50 $\mathrm{mg}, \mathrm{ADR} 10 \mathrm{mg})$ を行い, 1 力月後に肝右葉切除 術を施行した。手術時に左葉内側域に肝内転移を 認めたため, 楔状切除術も追加した。病理組織は, hepatoblastoma, poorly differentiated typeであ つた。その後, AP療法 $\left(\mathrm{ADR} 30 \mathrm{mg} / \mathrm{m}^{2} \times 2\right.$ days, CDDP $20 \mathrm{mg} / \mathrm{m}^{2} \times 5$ days）を 4 クール，TP療法

(THP $30 \mathrm{mg} / \mathrm{m}^{2} \times 2$ days, CDDP $20 \mathrm{mg} / \mathrm{m}^{2} \times 5$ days）を 2 クール施行した。化学療法終了後, 画 像上再発は認めず, AFPも測定感度以下となった ため退院となった。

退院後 4 力月目にAFPが再上昇し，CTにて両 肺野に転移巣を認めた。両肺転移巣切除術と自家 骨髄採取を行い, TECb療法 (THP $25 \mathrm{mg} / \mathrm{m}^{2} \times 2$ days, VP-16 $100 \mathrm{mg} / \mathrm{m}^{2} \times 5$ days, CBDCA 120 $\mathrm{mg} / \mathrm{m}^{2} \times 5$ days $) 1$ クール, FCEP療法（ 5 -FU $400 \mathrm{mg} / \mathrm{m}^{2} \times 1$ days, CPM $1,200 \mathrm{mg} / \mathrm{m}^{2} \times 1$ days, VP-16 $100 \mathrm{mg} / \mathrm{m}^{2} \times 5$ days, CDDP $20 \mathrm{mg} /$ $\mathrm{m}^{2} \times 5$ days) 2 クール, EI療法 (VP-16 100mg/ $\mathrm{m}^{2} \times 3$ days, IFO $2,500 \mathrm{mg} / \mathrm{m}^{2} \times 3$ days) 1 クー ルを追加した。THP $25 \mathrm{mg} / \mathrm{m}^{2}$, IFO $2,500 \mathrm{mg} /$ $\mathrm{m}^{2}, \mathrm{CDDP} 30 \mathrm{mg} / \mathrm{m}^{2} ， 5$-FU $600 \mathrm{mg} / \mathrm{m}^{2}$ を用いた 超大量化学療法と自家骨髄移植を行い, AFPは, 測定感度以下にならなかったものの，画像上転移 巣は認められなかったため，外来で経過観察とな
つた。

退院後 3 カ月より再びAFPが上昇したが，その 3 力月後にCTで両肺に $5 \mathrm{~mm}$ 大の転移巣を認め た (Fig. 2)。経過観察していたが，新たな転移巣 は出現せず, AFPも70ng/ml程度で推移したため, 他に転移は無いものと考之, 治療開始 2 年 8 力月 （退院後10力月）時に，腋窩正中切開第 6 肋間開 胸にて两側転移巣切除を施行し, AFPは測定感度 以下となった。

その後も外来で経過観察していたところ，治療 開始 5 年 2 力月（両肺部分切除後 2 年 6 力月）の 時点で, 再びAFPが徐々に上昇し, 3 力月後のCT にて左肺に $1 \mathrm{~cm}$ 弱の転移巣を認めたため, 胸腔鏡 による摘出術を施行した。転移巣は, 左肺舌区の 肺表面に近く，比較的容易に発見でき，エンドカ ッターにて切除した。術後再びAFPは測定感度以 下となり，術後 6 力月現在再発の徴候は認めてい ない。

症例 $2: 10$ 歳 7 力月, 男児 (Fig. 3 )。

既往歴：特記すべき事なし。

現病歴：腹部膨満, 嘔吐, 発熱を主訴とし, 近 医総合病院を受診した。腹部CTで肝両葉に腫瘤陰 影，胸部レントゲン写真で両肺に多発性の転移巣 を認め(Fig.4), AFP 1,223,990ng/mlと極めて 高值で, 肝芽腫と診断され, 当院小児科に紹介入 院となった。

入院後, 開腹肝生検を施行した。病理組織は, 

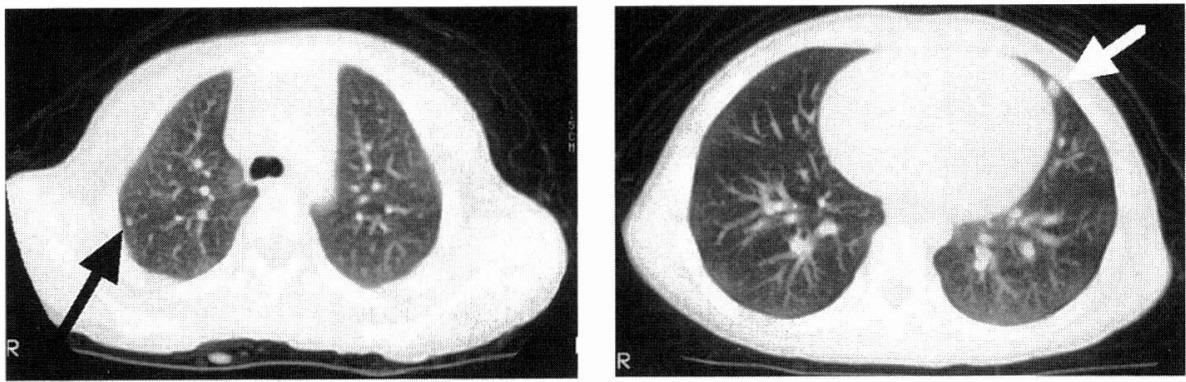

Case 1 (Recurrence lung metastases at Dec.1996)
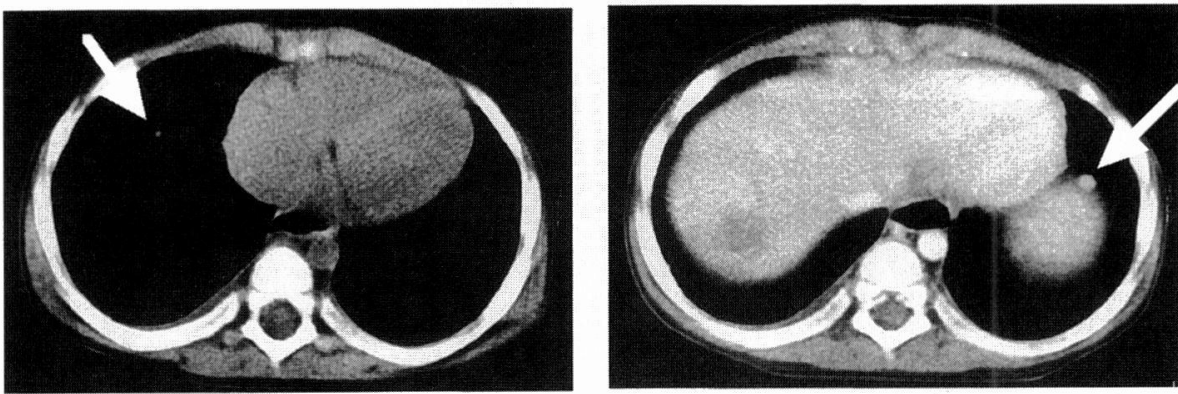

\section{Case 3 (at admission)}

Fig. 2 Lung metastases of cases 1 and 3 arrows: lung metastases

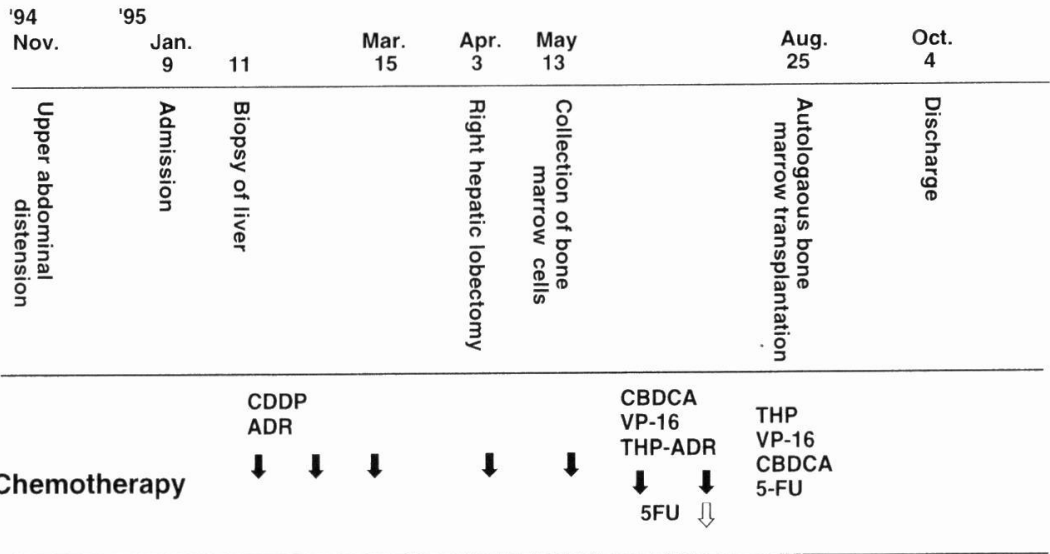

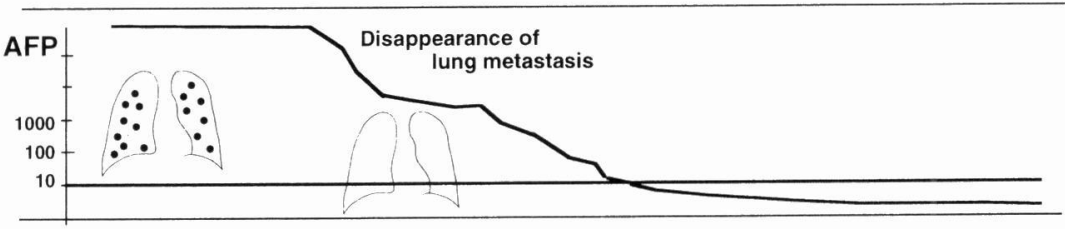

Fig. 3 Clinical course of case 2

hepatoblastoma, well differentiated typeであっ た。AP療法 3 クール終了後, 腫瘍は肝右葉に限局 L(Fig. 4), 胸部X線上肺転移は消失した。また, この時点で肝右葉切除術を施行した。AP療法 2 ク
ール追加し，AFP測定感度以下となった時点で自 家骨髄採取を行い, TECb療法 1 クール施行し, THP $30 \mathrm{mg} / \mathrm{m}^{2}$, VP-16 $200 \mathrm{mg} / \mathrm{m}^{2}$, CBDCA 400 $\mathrm{mg} / \mathrm{m}^{2}, \quad 5-\mathrm{FU} 600 \mathrm{mg} / \mathrm{m}^{2}$ にて超大量化学療法お 

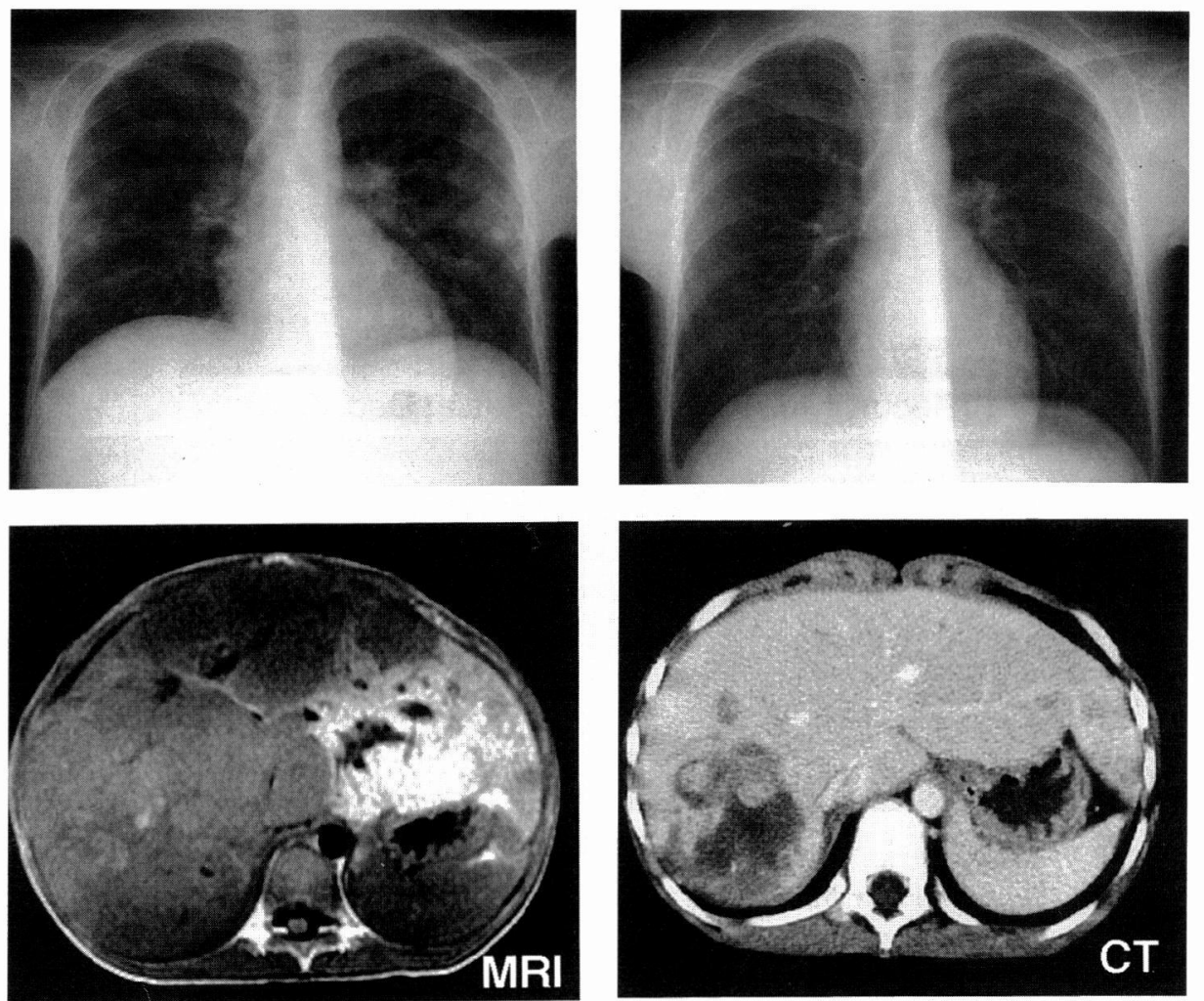

At admission

After 3 courses of chemotherapy

Fig. 4 Chest X-ray, MRI, and CT of case 2

よび自家骨䯣移植を施行した。自家骨髄移植後, 肝障害と並行してAFPの軽度上昇を認めたが，そ の後測定感度以下となった。治療終了後 5 年現在, AFPは測定感度以下であり, 画像上再発の徴候は 認めない。

症例 $3: 1$ 歳 2 力月, 男児 (Fig. 5)。

既往歴：特記すべき事なし。

現病歴：嘔吐，下痢，咳嗽を主訴に，近医受診 し加療されるが改善なかった。検査のため他医入 院したが, 意識消失をきたし, 腹部CTで肝内に腫 瘍を認め, 肝腫瘍内出血のためのショック状態と 診断され，当科に緊急入院となった。CT上肝右葉 に腫瘤を認め, 左葉にも結節状の腫瘍を認めた。 また，CT上両肺に転移巣を認めた ( Fig. 2)。AFP は, 641,180ng/mlと高値であった。

肝芽腫と診断し，TAEを行い出血をコントロー ルした後, AP療法を 3 クール, ECb療法 $(\mathrm{VP}-16$
$180 \mathrm{mg} / \mathrm{m}^{2} \times 3$ days, CBDCA $180 \mathrm{mg} / \mathrm{m}^{2} \times 3$ days） 1 クールを施行し, 肝両葉部分切除術を施 行した。病理組織は, hepatoblastoma, well differentiated typeであった。その後, TEP療法(THP $20 \mathrm{mg} / \mathrm{m}^{2} \times 3$ days, VP-16 $100 \mathrm{mg} / \mathrm{m}^{2} \times 5$ days, $\mathrm{CDDP} 20 \mathrm{mg} / \mathrm{m}^{2} \times 5$ days) を 2 クール追加したも のの, 肺転移は消失しないため, 腋窩正中切開に て第 6 肋間開胸で両肺転移巣切除および自家骨䯣 採取を行った。TP療法 1 クール後, AFPは測定感 度以下とはならず， $20.8 \mathrm{ng} / \mathrm{ml}$ であったが，LPAM $90 \mathrm{mg} / \mathrm{m}^{2}, \mathrm{VP}-16200 \mathrm{mg} / \mathrm{m}^{2}, \quad 5$-FU 600 $\mathrm{mg} / \mathrm{m}^{2}$ による超大量化学療法と自家骨髄移植を 施行した。その後もAFPは测定感度以下にはなら なかった。1 月月後より, AFPが徐々に増加し始 め, CTにて右下肺に転移巣を認めたため, 再び肺 部分切除術を施行し, 再度THP $25 \mathrm{mg} / \mathrm{m}^{2}$, CDDP $30 \mathrm{mg} / \mathrm{m}^{2}, \quad 5-\mathrm{FU} 600 \mathrm{mg} / \mathrm{m}^{2}$ を用いた超大量化学 
療法を行い, 自家骨髄移植を施行した。その後, AFPは測定感度以下となり，治療終了後 5 年現 在, AFPは測定感度以下で, 画像上再発は認めな W。

症例 4: 1 歳 9 力月, 男児 (Fig. 6)。

既往歴：特記すべき事なし。

現病歴：上腹部の膨隆を主訴に近医を受診し， 腹部腫瘤を認め, 当科紹介された。肝左葉に腫瘤 を認め, AFP 204,800ng/mlと高值で, 肝芽腫と
䛦断し, 拡大肝左葉切除術を施行した。病理組織 は, hepatoblastoma, well differentiated typeで あった。術後40日頃より, AFPの減少が増加へと 転じ，VCR，EDXによる化学療法を施行した。術 後 2 力月の胸部X線で, 右肺門部に転移を認めた。 その後, VCR, ADRによる化学療法を追加し, 化 学療法開始後約 2 力月の時点で, CT上転移は消失 L, AFPも測定感度以下となった。以後 16 年間 AFPは測定感度以下で，画像上再発を認めない。
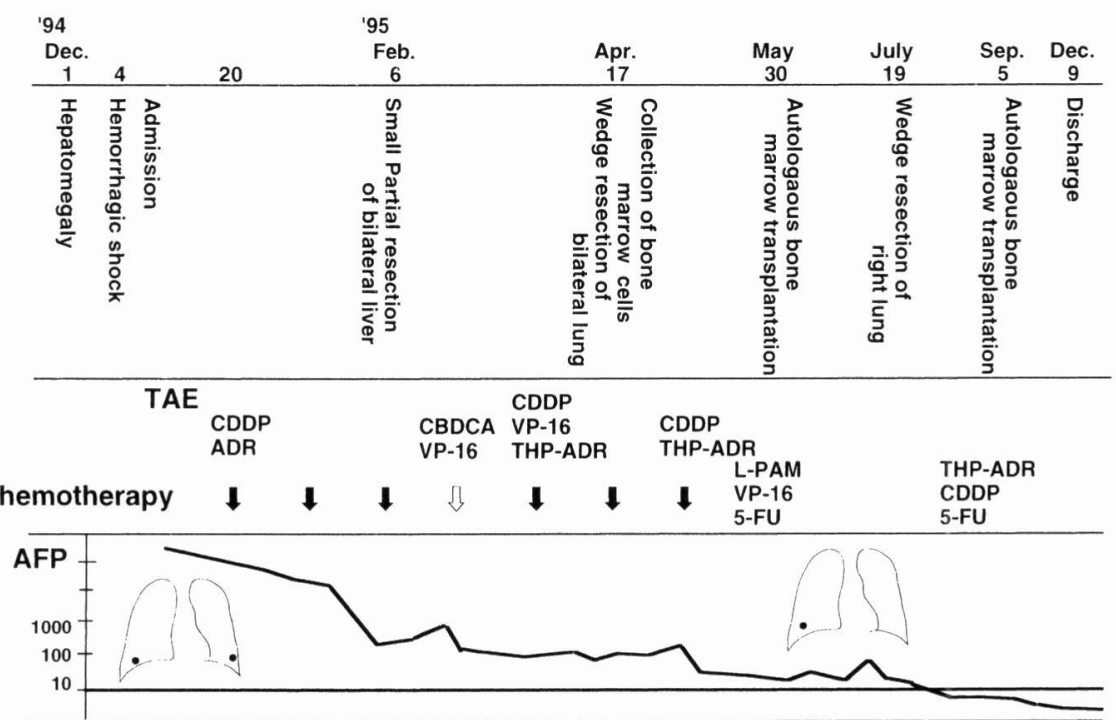

Fig. 5 Clinical course of case 3
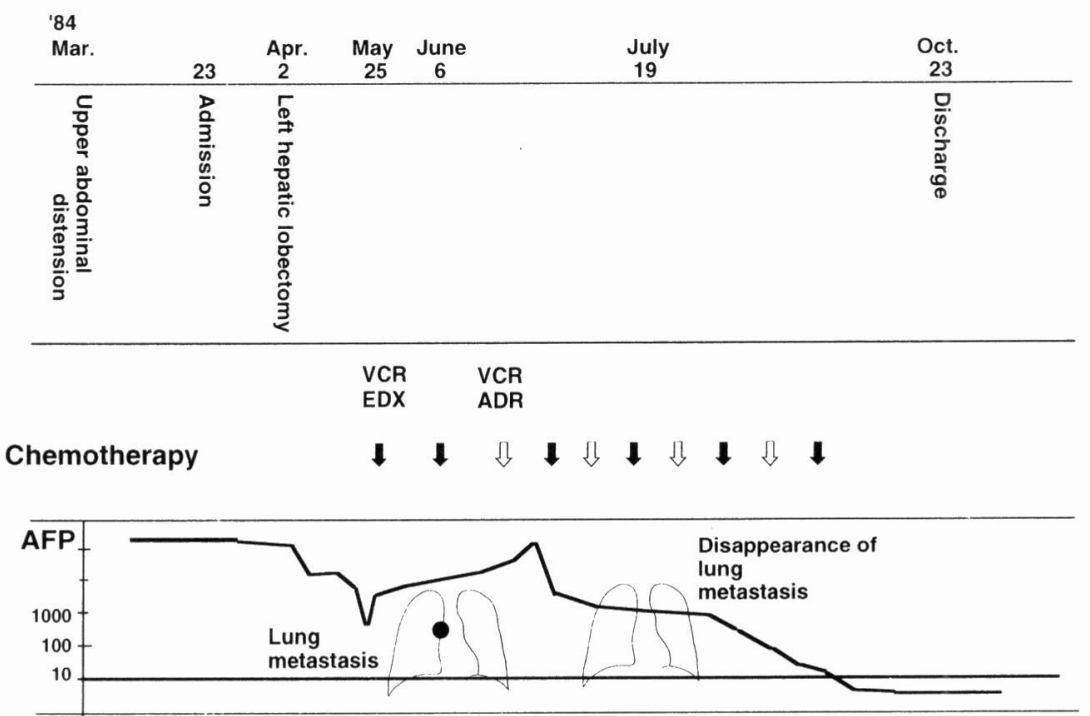

Fig. 6 Clinical course of case 4 
Table 1 Cases of hepatoblastoma with lung metastases

\begin{tabular}{|c|c|c|c|c|c|c|}
\hline Case & $\begin{array}{l}\text { Age at } \\
\text { dlag- } \\
\text { nosis }\end{array}$ & Sex & $\begin{array}{l}\text { Patho- } \\
\text { logy* }\end{array}$ & Staging & $\begin{array}{l}\text { Lung } \\
\text { metastases at } \\
\text { admission }\end{array}$ & $\begin{array}{l}\text { Status I } \\
\text { Tumor-free } \\
\text { survival period }\end{array}$ \\
\hline 1 & $3 Y 5 M$ & $\mathbf{M}$ & poorly & IIIa & $(-)$ & Alive / 6M \\
\hline 2 & $10 Y 7 M$ & $\mathbf{M}$ & well & IV & multiple & Alive / 5Y \\
\hline 3 & $1 Y 2 M$ & $M$ & well & IV & $\begin{array}{l}\text { solitary in } \\
\text { both lobe }\end{array}$ & Alive / 5Y \\
\hline 4 & 1Y9M & $\mathbf{M}$ & well & IIIa & $(-)$ & Alive / 16Y \\
\hline
\end{tabular}

\section{症例のまとめ}

症例はTable 1 のごとく, 全例男児で, 組織型は 症例 1 の well differentiated typeであった。初診時肺転移 は 2 例に認め，1例は化学療法で肺転移は消失し た。1例は化学療法を行うが消失せず，外科的摘 出術を行ったが，その後再発し，再手術を行い， 2 度目の骨髄移植を行って生存中の症例である。 治療中肺転移を示した症例は 2 例で，比較的古い 症例で，化学療法で転移は消失し，1例は外科的 摘出術を行った。術後 6 力月から 16 年で, 全例再 発の徴候なく生存中である。

\section{考察}

初診時肺転移を認めない症例で，治療中に肺転 移が出現する場合は，これは，化学療法が不十分 であったり，十分であっても薬剤耐性の腫瘍細胞 が肺転移を形成したものと考えられる。Feusner ら ${ }^{9} は ，$ 局所再発の認められない肝芽腫肺転移例 は，肺転移は診断時には存在していたもので，積 極的な転移巣の外科的治療が予後を期待できる主 な治療法であると述べている。

初診時より肺転移を認める症例は，転移巣とし て診断できない微小転移が存在するため術前化学 療法の適応である。症例 1 は, 超大量化学療法後, 自家骨髄移植を行った後に再び肺転移を認めた が，結果的には初診時の微小転移の再燃の可能性 が高く, 外科的切除術を 3 回行い, 現在再発を認 めていない。症例 3 は, 肺転移巣切除後AFPは正
常化しなかったが，画像上再発を認めないため, 超大量化学療法後, 自家骨髄移植を行った。超大 量化学療法を行ったにも関わらず，肺転移再発を 認め, 再び外科的切除術を行い, 再度超大量化学 療法および自家骨髄移植を行った。以上から，微 小転移が残存する可能性がある場合, 特にAFPが 重要な腫瘍マーカーである肝芽腫では，このAFP が測定感度以下とならない場合は，超大量化学療 法後に自家骨髄移植を行うのみでは，根治に至ら ない可能性が危惧される。特に，超大量化学療法 後の再発では，使用薬剂に限界があり，たと之化 学療法が無効でも, 積極的な外科的治療が有力な 手段となりうることを念頭においておく必要があ る。

微小肺転移の存在を有効に診断する手段が求め られる一方, 肺転移の高リスク群が明かになれば, 肺への放射線療法などを組み合せることで，根治 性を高めることが可能となる ${ }^{10)}$ 。岩㴊ら ${ }^{11)} は ， 1 ）$ 1 歳以上の症例， 2 )腫瘍重量が $500 \mathrm{~g}$ 以上の症例, 3 ) 腫瘍被膜の血管内に腫瘍塞栓を認める症例を 肺転移危険群として, 術後化学療法を行うことが 重要であると述べている。症例 4 は，1）1歳 9 力月， 2 ) 腫瘍重量 $510 \mathrm{~g}, 3$ ) は認めないものの, 岩渆らの報告に合致した症例であるが，16年前の 症例であり，化学療法を行わず様子観察を行い， 後に肺転移を認めた。

しかし,化学療法や放射線療法には限界があり， 呈示した症例のごとく積極的に外科的治療にて治 癒に至らしめた症例も少なくなく，肺転移に対す る外科的切除も有効な一手段とすべきである。

症例 $1 ， 3$ のよjに，肺転移がそれぞれ 1 個で あれば問題はないが，複数転移の場合，転移巣が いくつまで手術適応とするかという問題も生じ る。これは，全部切除可能なら数に関係なく手術 適応と考之，片肺で 9 個切除したとの報告もあ る ${ }^{12)}$ 。両側肺転移の場合，両側肺を同時に摘出する か，別々に摘出するか問題となるが，肺部分切除 であり，両側肺転移症例は 2 例とも同時に摘出し た。術後管理などで，特に難渋するようなことは なかった。また，手術が複数回に及ぶこともあり， 肺葉切除は侵襲が大きく，肺部分切除で十分と考 える。小児では，腋窩正中切開にて第 5 ないし 6 
肋間開胸で, 十分肺部分切除可能である。また, 繰り返す開胸にて胸郭の変形や胸郭運動の障害で

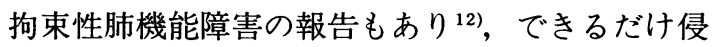
襲の少ない手術, 胸腔鏡手術が望ましいと考える。 症例 1,3 とも, 胸郭の変形は認めていない。

小児悪性腫瘍では， 2 年経過すれば治癒したも のと考之るが, 自験例のように, 術後 2 年以上経 過して肺転移再発を認めており，十分な観察が必 要であると考之られた。再発の早期発見のために は定期的なAFPの検査が重要である。悪性腫瘍の 経過観察では, CTを 3 力月毎に撮るべきとの報告 があり ${ }^{13)}$, 症例 1 では $\mathrm{AFP}$ 再上昇後 3 力月後に CT画像上再発を認めた。

\section{結 語}

肝芽腫の治療方針として, 初診時, 肺転移巣が 認められない場合は, 一期的に腫瘍切除可能なら ば切除し，化学療法を行う。一期的な腫瘍切除不 能の場合は, 化学療法を行い, delayed primary operationを行う。初診時に肺転移巣が存在する場 合は, 全例が術前化学療法の適応である。術前化 学療法が奏功し, 肺転移巣が消失した症例では, 原発巣の切除後, 化学療法を追加し, AFPの正常 化を待って超大量化学療法を行う。術前化学療法 後も肺転移巣が残存する場合は, 原発巣・肺転移 巣切除後, 化学療法を追加し, 超大量化学療法を 試みるべきである。

化学療法終了後または化学療法中に肺転移を認 めた場合は, 可及的に肺転移巣を切除し, 化学療 法を追加し, 超大量化学療法も適応となる。

肝芽腫肺転移 4 例中 3 例が化学療法が有効とさ れるwell differentiated typeであったため, 外科 的治療を組み合わせて良好な結果を得ている。し かし, 組織型によっては化学療法に抵抗性の症例 も存在し, これらの症例に対する外科切除の有効 性に問題が残ると考えられる。

症例 1 のように, 肺部分切除を複数回必要とす る場合もあるので，胸腔鏡下切除術も念頭にいれ るべき手技と考える。ただし, 胸腔鏡の場合, 肺
転移巣を明確にできない事も考えられ，VATS (Video-assisted thoracoscopic surgery) も考慮 すべき方法と考えられた。

また， 2 年間再発がないとはいえ，その後の再 発の可能性もあり，十分な経過観察が必要である と考えられた。

なお, 本論文の要旨は外科系連合学会第25回学術集 会（東京）にて発表した。

\section{参考文献}

1）須貝道博，清藤 大，鈴木伸作他：小児悪性固形 腫瘍肺転移例の検討。小児がん36：179-183, 1999

2) 大沼直躬，田辺政裕，吉田英生他：肝芽腫の集学 的治療の検討。小児がん $35 ： 521-524 ， 1998$

3）萩野教幸，岡部郁夫，岩田光正他：肺転移を伴っ た進行肝芽腫の 1 治験例. 小児外科 $23 ： 1039$ 1044,1991

4）加藤哲夫, 吉野裕顕, 蛇口達造他：肺転移を伴っ た肝芽腫の治療方針。小児外科27：71-79, 1995

5）川上 清, 高松英夫, 四位昭人他：肝芽腫肺転移 巣に有効な治療法. 小児外科 $27 ： 80-85,1995$

6）松下 卓, 矢島周平, 大平睦郎：自家骨髄移植を 行った肝芽腫の治療。小児外科 $27: 86-93,1995$

7）山口秀人, 石井榮一, 宮崎澄雄：肝芽腫と幹細胞 移植併用療法. 小児外科 $27 ： 1223-1227,1995$

8）西村真一郎, 藤田直人, 佐藤 貢他：肝芽腫肺転 移巣の治療。小児外科29：1437-1443，1997

9) Feusner JH, Krailo MD, Haas JE, et al : Treatment of pulmonary metastases of initial stage I hepatoblastoma in childhood. Cancer $71: 859$ 864,1993

10）大沼直躬，田辺政裕，吉田英生他：転移性肺腫瘍 の放射線療法。小児外科 $29 ： 1466-1470 ， 1997$

11）岩㴊 真, 広田雅行, 八木 実他：肝芽腫の肺転 移因子について。 小児外科 $23 ： 450-456,1991$

12）石田治雄, 林 奥, 鎌形正一郎他：転移性肺腫 瘍の外科療法。小児外科 $29 ： 1449-1455,1997$

13) La Quaglia MP : The surgical management of metastases in pediatric cancer. Semin Pediatr Surg $2: 75-82,1993$ 